\title{
PERBANDINGAN ANTARA EFEKTIVITAS METODE SIMULASI DENGAN CERAMAH TERHADAP PRESTASI BELAJAR PENDIDIKAN KEWARGANEGARAAN PADA MATERI POKOK HAK ASASI MANUSIA PESERTA DIDIK DI KELAS VII SMP MUHAMMADIYAH 30 SIHEPENG TAHUN PELAJARAN 2015-2016
}

\author{
Nurhalimah Riyana ${ }^{(1)}$ dan Abdul Aziz Abidan ${ }^{(2)}$ \\ ${ }^{(1)}$ Mahasiswa FKIP Universitas Muhammadiyah Tapanuli Selatan \\ ${ }^{(2)}$ Dosen Universitas Muhammadiyah Tapanuli Selatan
}

\begin{abstract}
Abstrak
Penelitian ini adalah untuk mengkaji perbandingan prestasi belajar peserta didik antara penggunaan metode simulasi dengan metode ceramah pendidikan kewarganegaraan pada materi pokok hak asasi manusia peserta didik di kelas VII SMP Muhammadiyah 30 Sihepeng Tahun Pelajaran 2015-2016. Dalam penelitian ini penulis menggunakan metode penelitian secara Asosiatif yaitu untuk mengetahui hubungan antara dua variabel atau lebih.Dan penelitian lapangan (field research)merupakan penelitian yang dilakukan secara langsung ke lokasi yang akan diteliti. Penulis menggunakan rumus t-test polled varians, yaitu :

$$
t=\frac{X_{1}-X_{2}}{\sqrt{\frac{\left(n_{1}-1\right) S_{1}^{2}+\left(n_{2}-1\right) S_{2}^{2}}{n_{1+} n_{2}-2}\left[\frac{1}{n_{1}}-\frac{1}{n_{2}}\right]}}
$$

Berdasarkan analisa di atas maka diperoleh nilai $t_{\text {hitung }}$ yaitu 0,506 dengan melihat daftar $t_{\text {tabel }}$ dengan jumlah sampel 48 kemudian digunakan derajat kebebasan $(d k)=n_{1}+n_{2}-2$ dan taraf kesalahan 5\% adalah 2,011 dengan demikian dapat diketahui $t_{\text {hitung }}$ lebih kecil dari $t_{\text {tabel }}$ yaitu 0,506 <2,011 maka hipotesis alternatif ( $\mathrm{Ha}$ ) dapat diterima, artinya ada perbandingan prestasi belajar antara yang menggunakan metode simulasi dengan metode ceramah pada materi pokok hak asasi manusia kelas VII SMP Muhammadiyah 30 Sihepeng Tahun Pelajaran 2015-2016.
\end{abstract}

Kata kunci : Efektivitas Metode Simulasi, Hak Asasi Manusia, Prestasi Belajar

\section{Pendahuluan}

Pendidikan merupakan salah satu yang dibutuhkan dalam kehidupan manusia dengan melalui pendidikan formal sehingga peran serta guru sangat dibutuhkan dalam kelangsungan proses pembelajaran di sekolah. Sejalan dengan pendidikan salah satunya adalah bagaimana guru itu mampu 
melakukan suatu proses perubahan terhadap peserta didik.

Sesuai dengan pendapat Saiful Sagala mengatakan bahwa : "Pendidikan merupakan pembentuk kemampuan dasar yang fundamental, baik menyangkut daya fikir atau daya intelektual, maupun daya emosional atau peranan yang di arahkan kepada tabiat manusia dan kepada sesamanya

Dengan demikian dapat disimpulkan bahwa pendidikan kewarganegaraan merupakan salah satu ilmu dasar dan ilmu pengetahuan yang memiliki peranan penting dalam kehidupan berbangsa dan bernegara atau bisa juga dikatakan sebagai ilmu sosial.

Pendidikan kewarganegaraan merupakan bagian pendidikan secara keseluruhan dan pendidikan kewarganegaraan mempunyai kedudukan yang sangat penting karena Pendidikan Kewarganegaraan merupakan pengetahıan dasar yang berhubungan langsung d 1 n IPTEK (Ilmu Pengetahuan dan Teknologi) dalam kehidupan sehari-hari. Pendidikan Kewarganegaraan juga mempunyai kedudukan sebagai pembantu cabangcabang ilmu pengetahuan lain yang memerlukan perhitungan, seperti Agama, Sosiologi, Sejarah, Kebudayaan, Ekonomi dan lain sebagainya.

Berdasarkan ini penulis ingin melakukan suatu penelitian tentang perbandingan antara efektivitas metode simulasi dengan ceramah terhadap prestasi belajar pendidikan kewarganegaraan pada materi pokok hak asasi manusia peserta didik di kelas VII SMP MUHAMMADIYAH 30 SIHEPENG Tahun Pelajaran 2015-2016.

Melihat uraian di atas terdapat prestasi belajar peserta didik rendah, karena peserta didik kurang memahami materi pelajaran yang diberikan oleh guru, sebab metode belajar yang diberikan guru sangat monoton, oleh karenanya penulis mencoba membandingkan metode ceramah yang sering diterapkan saat proses pembelajaran dengan metode simulasi yang dianggap mampu meningkatkan prestasi belajar peserta didik Pendidikan Kewarganegaraan.

Prestasi belajar sebagai penggerak yang mendorong seseorang untuk melakukan suatu perbuatan tertentu dalam rangka mencapai tujuan yang telah ditetapkan, termasuk perilaku belajar sangat penting karena motivasi tersebut akan menentukan intensitas usaha yang dilakukan seseorang. Dengan memiliki kreativitas yang besar akan terjadi pengungkapan potensi diri, proses peningkatan potensi dan pemanfaatan potensi.

Cara mengajar dengan ceramah dapat dikatakan juga sebagai teknik kuliah, merupakan suatu cara mengajar yang digunakan untuk menyampaikan keterangan atau informasi atau uraian tentang suatu pokok persoalan serta masalah secara lisan.

Dengan demikian, dapat dipahami bahwa metode ceramah adalah cara penyajian pelajaran yang dilakukan guru dengan penuturan atau penjelasan lisan secara langsung terhadap peserta didik. 
Sedangkan metode simulasi dikategorikan kedalam teknik atau metode yang kreatif karena membutuhkan imajinasi peserta didik yang mempunyai kreativitas akan lebih mudah dikembangkan. Begitu pula dengan semakin seringnya peserta didik menerapkan metode simulasi ini maka peserta didik akan semakin kreatif.

Di dalam pembelajaran ini peserta didik dibina kemampuannya berkaitan dengan keterampilan berinteraksi dan berkomunikasi dalam kelompok. Di samping itu, dalam metode simulasi peserta didik di ajak untuk dapat bermain peran beberapa perilaku yang dianggap sesuai dengan tujuan pembelajaran.

Dengan metode pembelajaran tersebut peserta didik dapat mendalami sebuah pelajaran dan dengan demikian secara tidak langsung akan menimbulkan kreativitas peserta didik dan berfikir untuk belajar, otomatis kegiatan belajar itu akan berlangsung secara kondusif.

Berdasarkan uraian di atas maka para pendidik (guru) dan para perancang pendidikan serta pengembang programprogram pembelajaran perlu menyadari akan pentingnya pemahaman terhadap hakikat belajar dan pembelajaran. Oleh karena itu para pendidik merancang pembelajaran seefisien mungkin. Sesuai dengan permasalahan yang dikaji didalam latar belakang masalah penelitian ini penulis ingin meneliti bagaimana pengaruh penggunaan metode simulasi dalam kemampuan berfikir peserta didik dalam proses belajar dan pembelajaran di kelas VII SMP Muhammadiyah 30 Sihepeng.

Metode pembelajaran simulasi ini belum pernah dilaksanakan pada peserta didik di kelas VII, metode ini memberikan cara belajar yang lebih membuka wawasan peserta didik untuk dapat memperagakan materi yang sedang diajarkan, agar peserta didik lebih mudah menerima pelajaran yang diberikan oleh guru. Diharapkan dengan metode simulasi ini dapat membuat peserta didik termotivasi. Adapun identifikasi masalah dalam penelitian ini adalah sebagai berikut:

1. Perlunya metode simulasi dalam pembelajaran pendidikan kewarganegaraan.

2. Kurangnya hasil dari metode ceramah dalam pembelajaran pendidikan kewarganegaraan.

3. Rendahnya prestasi belajar peserta didik.

\section{Metode Penelitian}

Lokasi merupakan wahana bagi penulis untuk melakukan penelitian. Penelitian ini dilaksanakan di Kelas VII SMP Muhammadiyah 30 Sihepeng Tahun Pelajaran 2015-2016, yang beralamat di Sihepeng I (satu), Kecamatan Siabu kabupaten Mandailing Natal. Adapun waktu penelitian dilaksanakan selama \pm 2 bulan, yaitu sejak selesainya seminar dan permohonan surat izin penelitian dikeluarkan dari Fakultas Keguruan dan dan Ilmu Pendidikan (FKIP) Universitas Muhammadiyah Tapanuli Selatan (UMTS) sampai selesainya penyusunan penelitian ini. 
Pendekatan Penelitian yang Digunakan Dalam penelitian ini yang sangat penting adalah pengumpulan data yang disajikan sebagai dasar dan pelengkap, maka untuk memperoleh data-data tersebut yang penulis lakukan adalah:

1. Penelitian Kepustakaan (Library Research)

Penelitian kepustakaan (library research) merupakan penelitian yang dilakukan dengan cara mengumpulkan datadata dan buku-buku literatur atau kepustakaan yang mempunyai hubungan erat dengan masalah yang dengan diteliti di lapangan.

\section{Penelitian Lapangan (field Research)}

Penelitian lapangan (field Research) merupakan penelitian yang dilakukan secara langsung ke lokasi yang akan diteliti. Pada kesempatan ini, penulis dapat langsung ke objek penelitian yaitu dikelas VII SMP Muhammadiyah 30 Sihepeng Tahun 2015-2016.

\section{Pembahasan dan Hasil}

Apakah guru memberikan bahan dengan metode simulasi disukai dalam bidang studi Pendidikan Kewarganegaraan?

\begin{tabular}{|c|l|c|c|}
\hline No & $\begin{array}{c}\text { Alternatif } \\
\text { Jawaban }\end{array}$ & Frekuensi & $\begin{array}{c}\text { F/N x } \\
100 \%\end{array}$ \\
\hline 1 & Selalu & 15 & 62,5 \\
\hline 2 & Sering & 7 & 29,17 \\
\hline 3 & $\begin{array}{l}\text { Kadang- } \\
\text { kadang }\end{array}$ & 2 & 8,33 \\
\hline
\end{tabular}




\begin{tabular}{|c|l|c|c|}
\hline No & $\begin{array}{c}\text { Alternatif } \\
\text { Jawaban }\end{array}$ & Frekuensi & $\begin{array}{c}\text { F/N x } \\
100 \%\end{array}$ \\
\hline 1 & Selalu & 8 & 33,33 \\
\hline 2 & Sering & 10 & 41,67 \\
\hline 3 & $\begin{array}{l}\text { Kadang- } \\
\text { kadang }\end{array}$ & 6 & 25 \\
\hline 4 & $\begin{array}{l}\text { Tidak } \\
\text { Pernah }\end{array}$ & - & - \\
\hline & \multicolumn{1}{|c|}{ Jumlah } & 24 & 100 \\
\hline
\end{tabular}

Dari jawaban di atas dapat disimpulkan bahwa guru menyuruh peserta didik mencoba kembali materi pokok, jika belum yakin dengan jawaban. Hal ini terlihat dari jawaban diberikan yaitu yang menjawab selalu 8 orang $33,33 \%$ yang menjawab sering 10 orang 41,67\% yang menjawab kadang-kadang 6 orang 25\%.

Apakah guru memberikan bahan dengan metode pembelajaran Ceramah disukai dalam bidang studi Pendidikan Kewarganegaraan?

\begin{tabular}{|c|l|c|c|}
\hline No & $\begin{array}{c}\text { Alternatif } \\
\text { Jawaban }\end{array}$ & Frekuensi & $\begin{array}{c}\text { F/N x } \\
100 \%\end{array}$ \\
\hline 1 & Selalu & 17 & 70,83 \\
\hline 2 & Sering & 6 & 25 \\
\hline 3 & $\begin{array}{l}\text { Kadang- } \\
\text { kadang }\end{array}$ & 1 & 4,17 \\
\hline 4 & $\begin{array}{l}\text { Tidak } \\
\text { Pernah }\end{array}$ & - & - \\
\hline & Jumlah & 24 & 100 \\
\hline
\end{tabular}

Dari jawaban di atas dapat disimpulkan bahwa dalam proses belajar mengajar guru memberikan bahan dengan metode Ceramah disukai dalam bidang studi Pendidikan Kewarganegaraan. Hal ini terlihat dari jawaban yang diberikan yaitu yang menjawab selalu 17 orang yaitu $70,83 \%$, yang menjawab sering 6 orang yaitu 25\%, dan yang menjawab kadangkadang 1 orang yaitu 4,17.

Apakah guru menginformasikan kepada peserta didik bagaimana menemukan ide pokok dengan metode Ceramah?

\begin{tabular}{|c|l|c|c|}
\hline No & $\begin{array}{c}\text { Alternatif } \\
\text { Jawaban }\end{array}$ & Frekuensi & $\begin{array}{c}\text { F/N x } \\
100 \%\end{array}$ \\
\hline 1 & Selalu & 6 & 25 \\
\hline 2 & Sering & 6 & 25 \\
\hline 3 & $\begin{array}{l}\text { Kadang- } \\
\text { kadang }\end{array}$ & 12 & 50 \\
\hline 4 & $\begin{array}{l}\text { Tidak } \\
\text { Pernah }\end{array}$ & - & - \\
\hline & Jumlah & 24 & 100 \\
\hline
\end{tabular}

Dari jawaban di atas dapat disimpulkan bahwaguru menginformasikan kepada peserta didik bagaimana menemukan ide pokok dengan metode Ceramah . Hal ini terlihat dari jawaban yang diberikan yaitu yang menjawab selalu 6 orang yaitu 25\%, yang menjawab sering 6 orang yaitu 25\%, yang menjawab kadang-kadang 12 orang yaitu 50\%.

Setelah dilakukan pengujian hipotesis diperoleh $t_{\text {hitung }}=0,484$ sedangkan nilai $t_{\text {tabel }}=2,011$, ini menunjukkan $t_{\text {hitung }}<$ $t_{\text {tabel }}$ artinya ada perbandingan prestasi belajar peserta didik antara metode simulasi dengan metode ceramah terhadap prestasi belajar Pendidikan Kewarganegaraan peserta didik kelas VII SMP Muhammadiyah 30 Sihepeng Tahun Pelajaran 2015-2016. 


\section{Kesimpulan}

Dari hasil penelitian dan analisa data yang diperoleh dari penelitian ini, penulis menarik kesimpulan yaitu:

1. Data yang diperoleh dengan teknik analisa data dengan menggunakan rumus t-test polled varians. Setelah dilakukan analisa data maka thitungnya adalah 0,484 dengan melihat daftar $t_{\text {tabel }}$ dengan jumlah sampel 48 dengan derajat kebebasan $(\mathrm{dk})=\mathrm{n}_{1}+\mathrm{n}_{2}-2$ dan taraf kesalahan 5\% adalah 2,011 dengan demikian dapat diketahui $t_{\text {hitung }}$ lebih kecil dari $t_{\text {tabel }}$ yaitu 0,484 $<2,011$ maka hipotesis alternatif (Ha) dapat diterima.

2. Perbandingan prestasi belajar peserta didik antara metode simulasi dengan metode ceramah terhadap prestasi belajar Pendidikan Kewarganegaraan peserta didik kelas VII SMP Muhammadiyah 30 Sihepeng Tahun Pelajaran 2015-2016. Diperoleh thitung $=0,506$ dan $t_{\text {tabel }}=2,011$, karena penulis berpatokan pada ketentuan jika $t_{\text {hitung }}<\mathrm{t}_{\text {tabel }}$ maka Ha diterima dan Ho ditolak, karena $t_{\text {hitung }}<t_{\text {tabel }}$ $0,506<2,011$. Jadi kesimpulan ada perbandingan antara kedua variabel tersebut karena Ho ditolak dan $\mathrm{Ha}$ diterima.

Dengan terkumpulnya data dalam penelitian ini yang diperoleh dan peserta didik kelas VII SMP Muhammadiyah 30 Sihepeng Tahun Pelajaran 2015-2016. Dengan penyebaran angket dan tes prestasi belajar. Setelah data terkumpul kemudian penulis mengadakan analisa dengan rumus ttest polled

varians.Berdasarkan perhitungan tersebut dapat disimpulkan bahwa hipotesis yang penulis ajukan dapat diterima dan benar kebenarannya.

\section{Saran}

Sebagai bagian akhir dari skripsi ini penulis mengajukan berbagai saran sebagai berikut:

1. Kepada peserta didik yang merupakan subjek belajar untuk lebih meningkatkan penguasaan terhadap materi pelajaran.

2. Kepada guru yang mengajar diharapkan dapat meningkatkan memampuan dalam mengajar dan selalu memperhatikan serta memotivasi peserta didik dalam kegiatan belajar mengajar. Disamping itu guru diharapkan dapat menggunakan metode belajar yang tepat dalam meningkatkan kemampuan peserta didik.

3. Sebagai bahan masukan bagi peneliti lainnya yang akan mengadakan penelitian pada permasalahan yang sama, guna memperkokoh data-data lain sehingga diperoleh hasil yang lebih baik dan bermanfaat di masa yang akan datang.

\section{Daftar Pustaka}

A. Ubaedillah dan Abdul Rozak, 2010,Pendidikan Kewarganegaraan (Civic Education), Jakarta: Kencana. 
Affan Gaffar, 2000,Politik Indonesia

Transisi Menuju Demokrasi, Yogyakarta: Pustaka Pelajar.

Ahmadi dan Prasetya. 2005. SBM strategi belajar mengajar. Bandung Pustaka Setia.

Arikunto, Suharsimi, 2000, Manajemen Penelitian. Jakarta: PT. Rineka Cipta.

Anitah, Sri,W, dkk. 2007, Strategi Pembelajaran di SD. Jakarta, Universitas Terbuka.

Asri, Zainal, 2010, Micro Teaching; Disertai dengan Pedoman Pengalaman Lapangan, Jakarta: Rajawali Pers.

Aswarni Sujud, Matra Fungsional Administrasi Pendidikan, (Yogyakarta: Purbasari, 1989).

Azis Wahab, Abdul, 2009, Metode Dan Model-Model Mengajar. Bandung: Alfabeta.

Azwar, Syarifuddin, 2010, Metode Penelitian. Yogyakarta: Pustaka Belajar.

Dimyati dan Mudjiono, 2006, Belajar Dan Pembelajaran. Jakarta: Rineka Cipta

Dewa Ketut Sukardi, 2003, Organisasi Administrasi Bimbingan dan Konseling di Sekolah, Surabaya: Usaha Nasional. 